\title{
Reaction of Xylenes with Benzyl Chloride in the Presence of Anhydrous Aluminium Chloride
}

\author{
Mahmud Hasan Tareque, Mohammad Ismail, Shams Tania Afroza Islam, \\ Mohammad Kamruzzaman and Manoranjan Saha \\ Department of Applied Chemistry and Chemical Technology, \\ University of Dhaka Dhaka-1000, Bangladesh.
}

\begin{abstract}
Reactions of ortho-, meta- and para-xylenes with benzyl chloride in the presence of anhydrous aluminium chloride as catalyst have been studied. The effects of variation of temperature, molar ratio of xylene to benzyl chloride, amount of catalyst and reaction time on the reactions have been investigated.
\end{abstract}

\section{Introduction}

Alkylaromatic hydrocarbons can be used as plasticizers, lubricating oil, transformer oil, pour point depressants, and grease. ${ }^{1-6}$ Reactions of aromatic hydrocarbons with benzyl chloride were investigated in the presence of different catalysts. ${ }^{7-9}$ But studies on the benzylation of xylenes with benzyl chloride in presence of anhydrous aluminium chloride are absent.

In the present work, the reactions of isomeric xylenes with benzyl chloride in the presence of anhydrous aluminium chloride have been investigated.

\section{Materials and Methods}

The reactions were carried out in a three necked round bottomed flask fitted with a condenser, a thermometer, a dropping funnel and a magnetic stirrer. Xylene and catalyst were charged into the flask and heated to the desired temperature and benzyl chloride was introduced into the mixture gradually for a certain period of time (time of addition) with constant stirring. The reaction mixture was stirred for another period of time (time of stirring) at the same temperature after the complete addition of total amount of benzyl chloride. The reaction mass was then cooled to room temperature, dissolved in petroleum ether, washed with distilled water several times and subjected to distillation. Unreacted reactants and solvent were distilled off at atmospheric pressure. The residual product was finally distilled and characterized by spectral means. 


\section{Results and Discussion}

\section{A. Benzylation of o-xylene}

Reaction of o-xylene with benzyl chloride was investigated in the presence of anhydrous aluminium chloride under different conditions. The reactions gave benzyl o-xylene. The effects of variation of different parameters on the yield of the product have been shown in Table I. yield increased also with the increase in temperature (Expt. no. 4 \& 5 and 6 \& 8) and reaction time (Expt. no. 5 and 6).

Thus, the product was obtained in 95.3\% yield under the following conditions: temperature $=100^{\circ} \mathrm{C}$, molar ratio of 0 -xylene to benzylchloride $=10: 1$, amount of anhydrous aluminium chloride $=1 \%$ by wt. of o-xylene, time of addition $=2 \mathrm{~h}$, time of stirring $=2 \mathrm{~h}$.

Table I. Benzylation of $\mathbf{0}$-xylene with benzyl chloride in presence of anhydrous aluminium chloride as catalyst

\begin{tabular}{|c|c|c|c|c|c|c|}
\hline \multirow[b]{2}{*}{$\begin{array}{c}\text { Expt. } \\
\text { No. }\end{array}$} & \multicolumn{5}{|c|}{ Reaction conditions } & \multirow{2}{*}{$\begin{array}{l}\% \text { Yield } \\
\text { of benzyl } \\
\text { o-xylene }\end{array}$} \\
\hline & $\begin{array}{l}\text { Temp., } \\
{ }^{\circ} \mathrm{C}\end{array}$ & $\begin{array}{c}\text { Molar ratio of } \\
\text { o-xylene to } \\
\text { benzyl chloride }\end{array}$ & $\begin{array}{c}\text { Amount of } \mathrm{AlCl}_{3} \text {, } \\
\text { \% by wt. of } \\
\text { o-xylene }\end{array}$ & $\begin{array}{c}\text { Time of } \\
\text { addition, } \mathrm{h}\end{array}$ & $\begin{array}{l}\text { Time of } \\
\text { stirring, h }\end{array}$ & \\
\hline 1 & 140 & 4:1 & 2 & 2 & 1 & 40.3 \\
\hline 2 & 140 & $6: 1$ & 2 & 2 & 1 & 52.5 \\
\hline 3 & 140 & 10:1 & 2 & 2 & 1 & 92.5 \\
\hline 4 & 140 & 10:1 & 1 & 2 & 1 & 92.3 \\
\hline 5 & 100 & 10:1 & 1 & 2 & 1 & 87.6 \\
\hline 6 & 100 & 10:1 & 1 & 2 & 2 & 95.3 \\
\hline 7 & 100 & 12:1 & 1 & 2 & 2 & 90.8 \\
\hline 8 & 70 & 10:1 & 1 & 2 & 2 & 63.3 \\
\hline
\end{tabular}

The yield of the product significantly increased with the increase in molar ratio (Expt. no. 1- 3).The yield decreased with further increase in molar ratio of o-xylene to benzyl chloride (Expt. no. 6 and 7). This was due to the reverse dealkylation reaction. The
Benzyl o-xylene showed strong absorption at $\lambda_{\max }=276.80 \mathrm{~nm}$ in $0.01 \mathrm{M}$ methanol solution in the UV spectrum.

The IR spectrum of the product showed absorption bands at $\mathbf{6 9 6 . 4} \mathbf{c m}^{-1}$ and $\mathbf{7 3 5 . 0}$ 
$\mathbf{~ c m}^{-1}$ for the presence of 1,2,3-trisubstituted benzene ring. Bands at $\mathbf{8 4 4} \mathbf{~ c m}^{-1}$ and $\mathbf{8 8 7 . 4}$ $\mathbf{~ c m}^{-1}$ accounted for 1,2,4-trisubstituted benzene ring. Absorption bands at $3030 \mathbf{~ c m}^{-1}$, $2982.2 \mathbf{~ c m}^{-1}$ and $1585 \mathbf{c m}^{-1}$ indicated the aromatic $=\mathrm{C}-\mathrm{H}$, saturated $\mathrm{C}-\mathrm{H}$ and benzene ring $\mathrm{C} \because \mathrm{C}$, respectively. m-xylene. The results of variation of various parameters have been summarized in Table III.

The yield of the product increased with the increase in molar ratio of m-xylene to benzylchloride upto a certain range. (Expt. no. 1-3). But the yield decreased when the molar

Table II. The ${ }^{1} \mathrm{H}$ NMR spectrum of benzyl o-xylene

\begin{tabular}{c|c}
\hline Observed signals of protons & Chemical shift in $\delta$ ppm \\
\hline All protons on two aromatic rings & $7-7.2$ \\
Two protons of $-\mathrm{CH}_{2}-$ on benzyl group & $4.3-4.5$ \\
Six protons on the two $-\mathrm{CH}_{3}$ groups & $1.2-1.8$ \\
\hline
\end{tabular}

\section{B. Benzylation of $\mathbf{m}$-xylene}

Benzylation of m-xylene with benzyl chloride in presence of anhydrous aluminium chloride as catalyst over the temperature range of $70-130^{\circ} \mathrm{C}$ produced benzyl ratio was increased further (Expt. no. 3 and 4). The yield increased significantly with the increase in temperature (Expt. no. 3 \& 6 and $5 \&$ 8), reaction time (Expt. no.6 and 7) and amount of catalyst (Expt. no. 3 and 5).

Table III. Benzylation of $\mathbf{m}$-xylene with benzyl chloride in presence of anhydrous aluminium chloride as catalyst

\begin{tabular}{c|c|c|c|c|c|c}
\hline \multirow{2}{*}{$\begin{array}{c}\text { Expt. } \\
\text { No. }\end{array}$} & $\begin{array}{c}\text { Temp., } \\
{ }^{\circ} \mathrm{C}\end{array}$ & $\begin{array}{c}\text { Molar ratio of m- } \\
\text { xylene to benzyl } \\
\text { chloride }\end{array}$ & $\begin{array}{c}\text { Amount of } \mathrm{AlCl}_{3}, \\
\text { \% by wt. of } \\
\text { m-xylene }\end{array}$ & $\begin{array}{c}\text { Time of } \\
\text { addition, h }\end{array}$ & $\begin{array}{c}\text { Time of } \\
\text { stirring, } \mathrm{h}\end{array}$ & $\begin{array}{c}\text { \% Yield } \\
\text { of benzyl } \\
\text { m-xylene }\end{array}$ \\
\hline 1 & 130 & $6: 1$ & 2 & 2 & 1 & 60.1 \\
2 & 130 & $8: 1$ & 2 & 2 & 1 & 73.1 \\
3 & 130 & $10: 1$ & 2 & 2 & 1 & 95.5 \\
4 & 130 & $12: 1$ & 2 & 2 & 1 & 94.3 \\
5 & 130 & $10: 1$ & 1 & 2 & 1 & 93.5 \\
6 & 70 & $10: 1$ & 2 & 2 & 1 & 55.9 \\
7 & 70 & $10: 1$ & 2 & 2 & 2 & 86.1 \\
8 & 100 & $10: 1$ & 1 & 2 & 1 & 88.3 \\
\hline
\end{tabular}


Thus, benzyl m-xylene was obtained in $95.5 \%$ yield under the following conditions: temperature $=130^{\circ} \mathrm{C}$, molar ratio of $\mathrm{m}$ xylene to benzylchloride $=10: 1$, amount of anhydrous aluminium chloride $=2 \%$ by wt. of m-xylene, time of addition $=2 \mathrm{~h}$, time of stirring $=1 \mathrm{~h}$.

The product showed strong absorption at $\lambda_{\max }=276.40 \mathrm{~nm}$ in $0.01 \mathrm{M}$ methanol solution in the UV spectrum.

In the IR spectrum of the product absorption bands at $696.4 \mathrm{~cm}^{-1}$ and $769.7 \mathrm{~cm}^{-1}$ accounted for 1,2,3-trisubstituted benzene ring. Bands at $831.4 \mathbf{~ c m}^{-1}$ and $875.8 \mathbf{~ c m}^{-1}$ showed 1,2,4-trisubstituted benzene ring. Absorption bands at $3026.7 \mathrm{~cm}^{-1}, \mathbf{2 9 2 0 . 6} \mathrm{cm}^{-1}$ and 1600 $\mathbf{c m}^{-1}$ accounted for the aromatic $=\mathrm{C}-\mathrm{H}$, saturated $\mathrm{C}-\mathrm{H}$ and benzene ring $\mathrm{C} \cdots \mathrm{C}$, respectively.
The yield of the product increased with the increase in molar ratio upto 10:1 (Expt. no. 14) and decreased with further increase in molar ratio (Expt. no. 4 and 5 ). The yield also increased with the increase in temperature (Expt. no. 4,6 and 7). But the yield decreased with the increase in reaction time due to dealkylation (Expt. no. 8 and 9).

Thus, 2-benzyl-1,4-dimethylbenzene was obtained in $96.5 \%$ yield under the following conditions: temperature $=130^{\circ} \mathrm{C}$, molar ratio of p-xylene to benzylchloride $=10: 1$, amount of anhydrous aluminium chloride $=2 \%$ by wt. of p-xylene, time of addition, $=2 \mathrm{~h}$ and time of stirring $=1 \mathrm{~h}$.

The product showed strong absorption at $\lambda_{\max }=277.80 \mathrm{~nm}$ in $0.01 \mathrm{M}$ methanol solution in the UV spectrum.

Table IV. The ${ }^{\mathbf{1}} \mathrm{H}$ NMR spectrum of benzyl m-xylene

\begin{tabular}{lc}
\hline \multicolumn{1}{c}{ Observed signals of protons } & Chemical shift in $\delta$ ppm \\
\hline All protons on two aromatic rings & $6.7-7.2$ \\
Two protons of $-\mathrm{CH}_{2}-$ on benzyl group & $3.7-3.9$ \\
Six protons on the two $-\mathrm{CH}_{3}$ groups & $2.1-2.3$ \\
\hline
\end{tabular}

\section{Benzylation of p-xylene}

Benzylation of p-xylene with benzyl chloride in the presence of anhydrous aluminium chloride as catalyst over the temperature range of 70 to $130^{\circ} \mathrm{C}$ produced 2-benzyl-1, 4-dimethylbenzene. The results are recorded in Table V.
In the IR spectrum of 2-benzyl-1, 4dimethylbenzene, absorption bands at $\mathbf{8 0 6 . 3}$

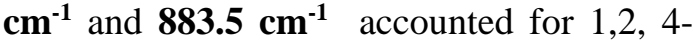
trisubstituted aromatic ring. Absorption bands at $3084.6 \mathrm{~cm}^{-1}, \mathbf{2 8 6 2 . 7} \mathrm{cm}^{-1}$ and 1603 $\mathbf{c m}^{-1}$ showed aromatic $=\mathrm{C}-\mathrm{H}$, saturated $\mathrm{C}-\mathrm{H}$ and aromatic ring $\mathrm{C}=\mathrm{C}$, respectively. 
Table V. Benzylation of p-xylene with benzylchloride in presence of anhydrous aluminium chloride as catalyst

\begin{tabular}{c|c|c|c|c|c|c}
\hline \multirow{2}{*}{$\begin{array}{l}\text { Expt. } \\
\text { No. }\end{array}$} & $\begin{array}{c}\text { Temp., } \\
{ }^{\circ} \mathrm{C}\end{array}$ & $\begin{array}{c}\text { Molar ratio of } \\
\text { p-xylene to } \\
\text { benzyl chloride }\end{array}$ & $\begin{array}{c}\text { Amount of } \\
\mathrm{AlCl}_{3}, \\
\text { \% by wt. of } \\
\text { p-xylene }\end{array}$ & $\begin{array}{c}\text { Time of } \\
\text { addition, h }\end{array}$ & $\begin{array}{c}\text { Time of } \\
\text { stirring, h }\end{array}$ & $\begin{array}{c}\% \text { Yield } \\
\text { of the } \\
\text { product }\end{array}$ \\
\hline 1 & 130 & $4: 1$ & 2 & 2 & 1 & 57.1 \\
2 & 130 & $6: 1$ & 2 & 2 & 1 & 62.5 \\
3 & 130 & $8: 1$ & 2 & 2 & 1 & 67.8 \\
4 & 130 & $10: 1$ & 2 & 2 & 1 & 96.5 \\
5 & 130 & $12: 1$ & 2 & 2 & 1 & 88.4 \\
6 & 100 & $10: 1$ & 2 & 2 & 1 & 90.8 \\
7 & 70 & $10: 1$ & 2 & 2 & 1 & 82.8 \\
8 & 100 & $10: 1$ & 1 & 2 & 1 & 92.9 \\
9 & 100 & $10: 1$ & 1 & 2 & 2 & 87.2 \\
\hline
\end{tabular}

Table VI. The ${ }^{1} \mathrm{H}$ NMR spectrum of 2-benzyl-1,4-dimethylbenzene

\begin{tabular}{l|c}
\hline \multicolumn{1}{c|}{ Observed signals of protons } & Chemical shift in $\boldsymbol{\delta}$ ppm \\
\hline Two aromatic ring protons & $6.7-7.2$ \\
Two protons of $-\mathrm{CH}_{2}-$ on benzyl group & $3.7-3.9$ \\
Six protons on the two $-\mathrm{CH}_{3}$ groups & $2.0-2.3$ \\
\hline
\end{tabular}

\section{References}

1. A. B. Vol-Epstein, A. A. Krichko and G. F. Filippychev. Neftepererabotkai Neftekhim. Nauuchn, Tekhn. Sb, 6 (1964) 33.

2. A. I. Akhmedov, A. N. Lerslina and E. U. Isakov. Khim. Tekhnol. Topl. Masel, 10 (1987) 26.
3. $\quad$ N. N. Bataafsche. de Dutch, 70 (1952) 426.

4. M. A. Ashimov, M. A. Mursalova and S. E. Kanzaveli. Dolk. Akad. Nauk. Azerb. 25(7) (1969) 20.

5. N. N. Lebedev, I. V. Nicolseu, I. Mircha and G. I. Nikshin. Izvest, Akhd. Nauk. USSR, Otdel. Khim, (1960) 94. 
6. J. R. Allion and Nm. L. Balack. US. Patent. 2(628) (1953) 95-202

7. A. A. Gevorkyan, A. S. Arakelyan and A. A. Dzhaninyan. Arm. Khim. Zh, 43(8) (1990) 523-525.
8. M. Akatsu, H. Takayama and M. Takeshi. Eur, Pat. Appl. EP, (1991), 428, 081 (Cl. C07C15/16)

9. Yu. V. Pozdnyakovich, R. P. Savyak, G. B. Kondratova and S. M. Shein. Zh. Org. Chem, 23(12) (1987) 2597-2602. 
Ahmed, Haque, Hossain, Rahman, Alamgir and Jalal 
